\title{
Application of Non Ionic Surfactant - Alkylpolyglucoside as Chemical Flooding
}

\author{
Agnesya Putri Gustianthy, Yuni Krisyuningsih Krisnandi, and Usman
}

\begin{abstract}
Alkylpolyglucosides
(APG) is an environment-friendly surfactant prepared from renewable raw materials namely glucose and fatty alcohol in catalysis system of p-Toluenesulfonic acid. This surfactant is nonionic surfactant which has not effect on hard water and $\mathrm{pH}$ changes, thus makes it potential to be used as a chemical flooding surfactant. APG was prepared by using fatty alcohol varying in chain length from 1-dodecanol (C12) and 1-tetradecanol (C14). This paper discusses the effect of alkyl chain length of APG as hydrofobic side to their physical properties such as interfacial tension, and capability as chemical flooding surfactant for oil recovery in capillary pressure test. As results, it is shown that at the same concentration, APG with 1-tetradecanol (APG-C14) as a chain length has lower interfacial tension than APG-C12, having critical micelle concentration of $3 \%$. Both surfactant then were tested for Jirak field oil recovery in capillary presure test. It reveals that the increase of alkyl chain length of APG causes an increase in oil recovery (\%), $13.797 \%$ of APG-C14 and $10.733 \%$ of APG-C12. To conclude, APG with long alkyl chain length potentially become chemical flooding surfactant for oil recovery.
\end{abstract}

Index Terms-Chemical flooding, nonionic surfactant, alkylpolyglucoside, fatty alcohol, interfacial tension.

\section{INTRODUCTION}

Recently enhance oil recovery (EOR) technology is getting more attention by many countries since energy crises are getting worse and frightened. In fact, when an oil reservoir is drilled, the oil amount obtained from the reservoir is about $45 \%$ of the potential, and hence there is still $55 \%$ oil left in rocks of the reservoir because conventional method is still used [1]. The Enhanced Oil Recovery (EOR) method is basically a method of acquiring petroleum by injecting an material / energy that aims to increase petroleum production after the primary and secondary production periods. Techniques included in EOR are thermal flooding, gas injection, chemical flooding and others. But not all EOR techniques can be applied in the oil field. This is because the process of applying EOR technology is influenced by the condition of the oil field which includes the types of rocks found in the reservoir, depth, temperature and pressure of the reservoir and reserves of energy sources that can be utilized as EOR [2]

Manuscript received February 4, 2019; revised May 9, 2019.

Agnesya Putri Gustianthy was with Department of Chemistry UI, Indonesia. She is now with Material and Chemical Research, Research Technology Centre of PT Pertamina, Indonesia (e-mail: agnesya.putri@pertamina.com).

Yuni K. Krisnandiis is with the Departement of Chemistry UI, Indonesia (e-mail: yuni.krisnandi@sci.ui.ac.id)

Usman is with Chemical and Petrochemical Research, Research and Technology Centre of PT Pertamina, Indonesia (e-mail: usman01@pertamina.com).
The petroleum industry has typically used mechanical (steam/ $/ \mathrm{CO}_{2}$ ) and chemical (polymer/surfactant) EOR processes to increase production in oil and gas reservoirs. Because most the oil reservoir have already begun with water flooding, chemical EOR or chemical flooding may be implemented using fewer resources than other EOR methods. In this study, chemical flooding, one of chemical EOR processes, was investigated.

The application of surfactant EOR improves the recovery of residual oil from known deposits by using a surface-active agent to reduce interfacial tension (IFT) to mobilize the residual oil. The surfactant needed to obtain good phase behavior and ultra-low IFT varies greatly with oil characteristics and reservoir conditions [3]. Four primary mechanisms are used to enhance oil recovery with the help of surface-active additives: (1) the generation of very low IFT $\left(<10^{-3}\right.$ dyne/cm) between the oil and the water flooding solution, (2) the spontaneous emulsification or microemulsification of the trapped oil, (3) the reduction of the interfacial rheological properties at the oil-aqueous solution interface, and (4) controlling the wettability of rock pores to optimize the oil displacement [4].

Generally, surfactants used in chemical flooding are petroleum and sulfonate-based surfactants, which are not environment-friendly and their resources are decrease [5]. Therefore, in the last decade the world has moved forward to a new class of surfactant that are made of natural renewable materials. These are surfactant alkyl glucosides, which are known traditionally as alkyl polyglucosides (APG). The raw materials for APG are carbohydrates and fatty alcohols, which are naturally occurring and renewable. During the synthesis of glucosides, a polyfunctional sugar component is combined with a nucleophile, such as alcohol, carbohydrate, or protein [6]. Surfactant APG known as nonionic surfactant. Nonionic surfactant do not produce ions in aqueous solution. As a consequence, they are compatible with other type and are excellent candidates to enter complex mixtures. Nonionic surfactants are much less sensitive to electrolytes, particularly divalent cations, that ionic surfactants, and can be used with high salinity or hard water [7]. The aim of our study was to apply an indirect method to prepare a series of APG with different alkyl chain lengths using the condensation reaction of glucose and fatty alcohols with different alkyl chain lengths ( $\mathrm{C} 12$ and $\mathrm{C} 14$ ) and to evaluate the prepared compounds as chemical flooding for EOR.

\section{Procedure}

\section{A. Material and Characterization}

All chemicals for synthesis were purchased from commercial suppliers in analytical grade and used without 
further purification. Evaluation surface-active properties and capillary pressure measurement material were used Water Produce (WP) and Oil from Jirak reservoir, Table I and Table II were shown characteristic of WP and oil of Jirak. Structure prepared APG was confirmed by Fourier Transform Infrared (FTIR). The FTIR spectrum was recorded using a Shimadzu IRPrestige-21 Spectrometer over range of $750-4000 \mathrm{~cm}^{-1}$.

TABLE I: CHARACTERISTIC OF JIRAK OIL

\begin{tabular}{lc}
\hline \hline Parameter & \\
\hline Viscosity @ 40 $40^{\circ} \mathrm{C}, \mathrm{cSt}$ & 5.0287 \\
Density@ $40^{\circ} \mathrm{C}, \mathrm{g} / \mathrm{cm}^{3}$ & 0.8501 \\
API Gravity, ${ }^{\circ} \mathrm{API}$ & 32.7 \\
Saturated Hydrocarbon, \% & 60.68 \\
Aromatic Hydrocarbon, \% & 35.36 \\
Resin, \% & 1.38 \\
Asphaltenes, \% & 2.58 \\
\hline
\end{tabular}

TABLE II: CHARACTERISTIC OF JiRAK WATER PRODUCE (WP)

\begin{tabular}{lc}
\hline \hline Parameter & \\
\hline TDS, mg/l & 17186.8 \\
$\mathrm{pH}$ & 8.26 \\
Density, g/ml & 1.0181 \\
Salinity, ppm & 12897 \\
\hline
\end{tabular}

\section{B. Synthesis of Alkyl Polyglucosides Using Indirect} Method (Transglycosidation)

A measure of 1.0 mole of glucose was dissolved in 5.9 mole butanol in the presence of $p$-Toluenesulfonic acid with azeotropic removal of water at $150{ }^{\circ} \mathrm{C}$ for $2 \mathrm{~h}$. Then, 3 mole of 1-dodecanol / 1-tetradecanol (higher alcohol) and half from first dosage $p$-Toluenesulfonic acid was added with decreasing to $120{ }^{\circ} \mathrm{C}$ for $2 \mathrm{~h}$. After that, the reaction mixture was neutralized with the addition of alcoholic $\mathrm{NaOH}$ to stop the reaction at $80{ }^{\circ} \mathrm{C}$. Excess alcohol was removed by distillation at $120{ }^{\circ} \mathrm{C}$ for butanol and $180{ }^{\circ} \mathrm{C}$ for higher alcohol under high vacuum $(100 \mathrm{~mm} \mathrm{Hg})$. The obtained yield was a black-brown color surfactant.

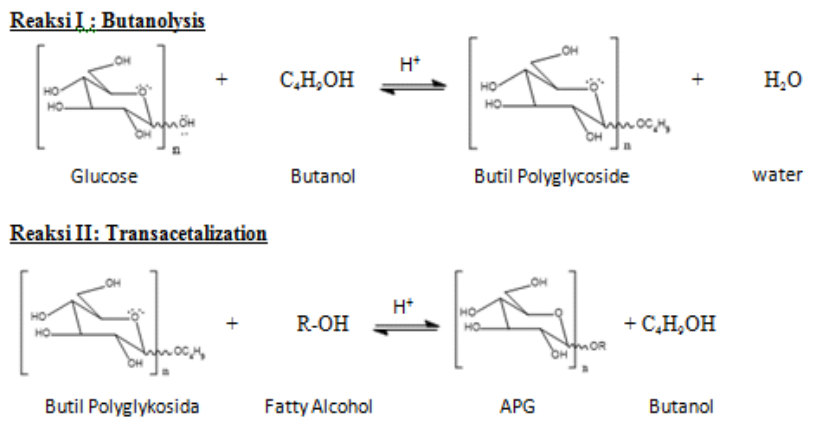

Fig. 1. Mechanism reaction of synthesis APG.

\section{Interfaial Tension (IFT)}

Surfactant APG was dissolved in water produce of Jirak reservoir with different concentrations. The IFT measurement of APG solution is using spinning drop tensiometer M6500. Different concentrations was used, ranging from $0.1-2 \%$ at $40{ }^{\circ} \mathrm{C}$ and $6000 \mathrm{rpm}$ for 30 minutes. Determined of IFT based on the following equation: where,

$$
\gamma=1.44 \times 10^{-7} \times \Delta \rho \times D^{3} \times \theta^{2}
$$

$\gamma$ is interfacial tension, dyne/cm

$\Delta \rho$ is the difference in density between surfactant and oil, $\mathrm{g} / \mathrm{cm}^{3}$

$\mathrm{D}$ is diameter, $\mathrm{mm}$

$\theta$ is rotation speed, $\mathrm{rpm}$

\section{Critical Micelle Concentration (CMC) Measurement}

The Critical Micelle Concentration (CMC) values were determined for APG with low IFT with interfacial tension method.

\section{E. Phase Behaviour Measurement}

A measure of $5 \mathrm{~mL}$ crude oil of Jirak was added to $5 \mathrm{~mL}$ surfactant solution in modified mohr pippete. Modified mohr pippete with sample are shaken for $30 \mathrm{~s}$, and then store in the oven at $40{ }^{\circ} \mathrm{C}$.

\section{F. Capillary Pressure Test}

The capillary pressure test method was carried the RC 4500 series CAPRI Centrifuge instrument. The material used for the application test is Berea upper gray sandstone grade synthetic rock with a max length $5 \mathrm{~cm}$ and diameter $\pm 3.7 \mathrm{~cm}$, and water produce of Jirak is used. Before the capillary test begins, several steps of core preparation was carried out which include testing the absolute permeability gas of core using permeameter instrument, pore volume measurement and core porosity referring to the API RP-27 method. After that, prepared core will be tested with autosaturator. Capillary pressure values are calculated by the following equation:

$$
P c=\frac{\Delta \rho}{2}\left(\frac{2 \pi N}{60}\right)^{2}\left(R_{E X T}^{2}-R_{I N T}^{2}\right)
$$

where,

$P c$ is interfacial tension, dyne/cm

$\Delta \rho$ is the difference in density between surfactant and oil, $\mathrm{kg} / \mathrm{m}^{3}$

$N$ is rotation speed, round per minute (rpm)

$R_{E X T}$ is distance between the rotating axis and the surface of the sample of the outer core, $m$

$R_{I N T}$ is distance between the rotating axis and the sample surface of the inner core, $\mathrm{m}$

Capillary pressure test carried out in three steps, drainage method using Jirak oil, imbibition method using WP jirak and Surfactant APG-12; APG-14 with pressure varying between 1- $45 \mathrm{psi}$ at $4000 \mathrm{rpm} ; 40{ }^{\circ} \mathrm{C}$ (water flooding and surfactant flooding). All measurement will completed when no changes in the system. Drainage method is a process of fluid flow where the wetting phase (water) saturation decreases and non-wetting phase (oil) saturation increases. In this case the oil functions as a driving fluid, so that water can be produced along with the addition of the pressure given. Water saturation value in the drainage method is calculated by the following equation:

$$
S w=S w i-\left(\frac{\text { vol. water out }}{P V}\right) \times 100 \%
$$

where,

$S w$ is water saturation, $\%$ 
Swi is initial water saturation, \%

Vol. water out is volume water out when injected by oil, cc

$P V$ is pore volume of core sample, $\mathrm{cc}$

Imbibition method is a process of fluid flow where the wetting phase (water) saturation increases, while non wetting phase (oil) saturation decreases. In this case the water functions as a driving fluid, so that oil can be produced with the addition of the pressure given. Water saturation value on the imbibition method is calculated by the following equation:

$$
S w=S w i r+\left(\frac{\text { vol. oil out }}{P V}\right) \times 100 \%
$$

where.

$S w$ is water saturation, $\%$

Swir is irreducible water saturation, $\%$

\section{RESUlt AND DISCUSSION}

\section{A. Synthesis of Surfactant APG}

Synthesis of APG with varying alkyl chain length were determined. Reaction of synthesis was carried out in two step (indirect method) with acid catalytic and high temperature, that make the product were with black-brown in color. This study used PTSA as acid catalyst. PTSA catalyst is used because it is non-oxidative so it does not oxidize butanol. Synthesis of alkyl polyglucoside surfactant is carried out through two steps of reaction, namely butanolysis and transacetalization. Based on the reaction, the mechanism butanolysis and transacetalization are shown in Fig. 1. The reaction is highly selective due to the hemiacetal/acetal function in the glucose molecule and resulting reactivity of the $\mathrm{OH}$ group at $\mathrm{C}_{1}$.

\section{B. Characterization of Surfactant $A P G$}

Characterization of the APG-12 was analyzed by FTIR spectroscopy and mass spectra. The characteristic absorption of ether linkage (C-O-C) formed due to $\mathrm{OH}$ condensation is a weak band in the range $1715-1722.43 \mathrm{~cm}^{-1}$ in addition to the bonds of active group reactants [8]. The infrared spectra of the prepared compounds showed different peaks that were characterized ( Fig. 2). Another comparison peak of prepared APG-C12 and APG-C14 are shown in Table III

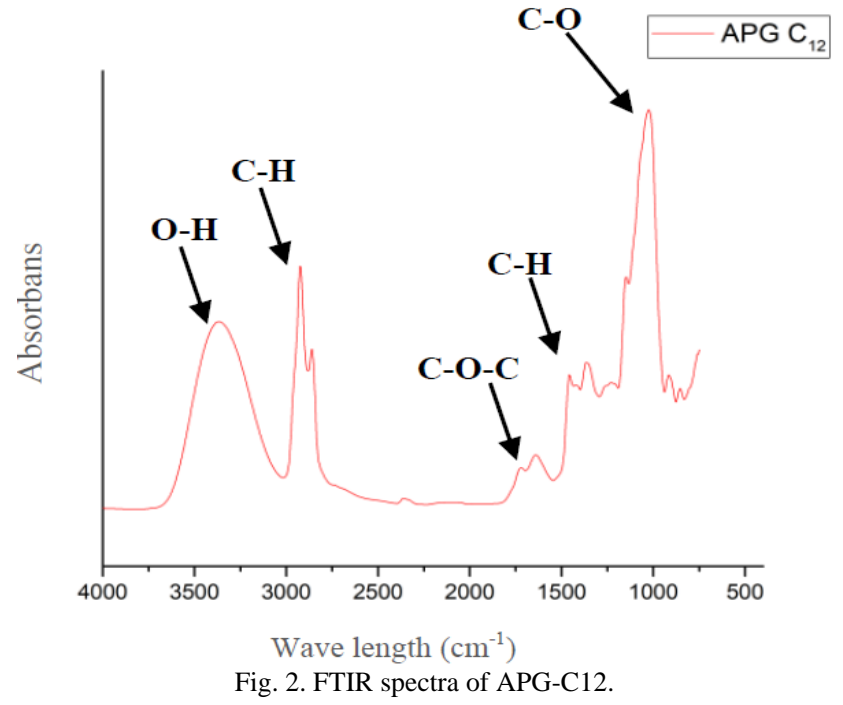

TABLE III: CHARACTERISTIC PEAKS OF THE PREPARED APG

\begin{tabular}{|c|c|c|c|c|c|}
\hline \multirow[b]{2}{*}{$\begin{array}{l}\text { Function } \\
\text { group }\end{array}$} & \multicolumn{5}{|c|}{ Wave no. $\left(\mathrm{cm}^{-1}\right)$} \\
\hline & $\begin{array}{c}\mathrm{C}_{12} \mathrm{APG} \\
{[5]}\end{array}$ & $\begin{array}{c}\mathrm{C}_{14} \mathrm{APG} \\
{[5]}\end{array}$ & APG [8] & $\begin{array}{c}\text { APG-C12 } \\
\text { (synthesis } \\
\text { product) }\end{array}$ & $\begin{array}{c}\text { APG-C14 } \\
\text { (synthesis } \\
\text { product) }\end{array}$ \\
\hline \multicolumn{6}{|l|}{$\mathrm{C}-\mathrm{H}$} \\
\hline $\begin{array}{l}\text { Symmetric } \\
\text { bending }\end{array}$ & 1375 & 1376 & & 1359.82 & 1377.17 \\
\hline $\begin{array}{l}\text { Asymmetric } \\
\text { bending }\end{array}$ & 1454 & 1463 & & 1456.26 & 1465.90 \\
\hline $\begin{array}{l}\text { Symmetric } \\
\text { stretch }\end{array}$ & 2865 & 2865 & & 2854.65 & 2852.72 \\
\hline $\begin{array}{l}\text { Asymmetric } \\
\text { stretch }\end{array}$ & 2960 & 2955 & & 2924.09 & 2920.23 \\
\hline $\mathrm{O}-\mathrm{H}$ & $\begin{array}{c}3200-34 \\
00\end{array}$ & $\begin{array}{c}3200-3 \\
400\end{array}$ & & 3332.99 & 3346.50 \\
\hline $\mathrm{C}-\mathrm{O}$ & 1055 & 1040 & & 1020.34 & 1026.13 \\
\hline $\begin{array}{l}\mathrm{C}-\mathrm{O}-\mathrm{C} \\
\text { acetal }\end{array}$ & 1716 & 1715 & 1716.65 & 1716.65 & 1722.43 \\
\hline
\end{tabular}

\section{Interfacial Tension (IFT) Determination}

Interfacial tension (IFT) measurement is one of the important parameters for determining whether a type of surfactant can be used for chemical flooding applications or not. Synthesized surfactants are expected to have interfacial tension values $\leq 10-3$ dyne $/ \mathrm{cm}$. Lower interfacial tension show better performance of surfactants as chemical flooding, because the interfacial tension value indicates the ability of surfactants to change the interfacial tension of crude oil and water that makes crude oil easily flow and carry over to production wells.

As the APG dissolves in solution, it migrates to the surface of water, reducing its surface tension. In contrast, the hydrophobic part of the molecule repeals the water molecules, moving upwards to the air while the head of the molecule is still in water, which results in a reduction of the surface tension of the air/water boundary. Increasing the APG concentration increases the migration of the molecules to the surface up to defined concentration at which the surface becomes saturated [5].

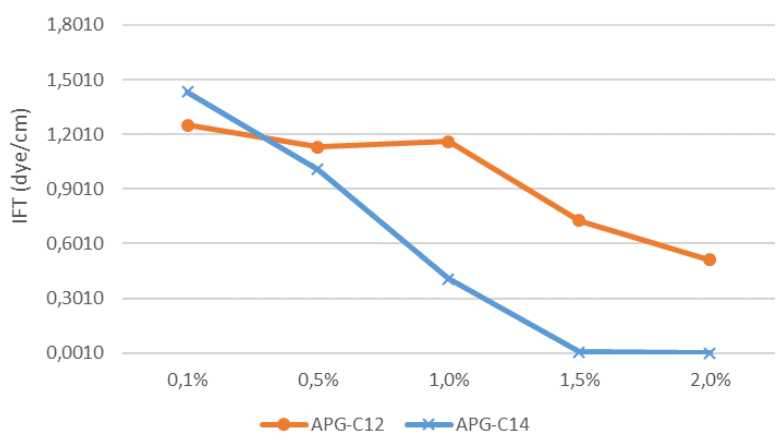

Fig. 3. Interfacial tension of APG-C12 and APG-C 14 at $40^{\circ} \mathrm{C}$.

The interfacial tension on the prepared APG-12 and APG-14 solution at different concentrations was measured with Jirak oil at $40{ }^{\circ} \mathrm{C}$. From interfacial tension measurement will get a picture of oil droplets which will be calculated in diameter to be used in calculating interfacial tension. Fig. 3 shows the variation in interfacial tension of the prepared surfactant againts the concentration range. As shown at Fig. 3 the surface tension decreases steadily as the surfactant concentration increases, the result show that surfactant IFT APG-14 has lower IFT value than surfactant APG-12. The 
lowest IFT value at $2 \%$, respectively surfactant APG-12 0.5137 dyne/cm and APG-14 0.0022 dyne/cm. The interfacial tension values for solutions of the prepared surfactants are greatly affected by the hydrophobic chain length of the alkyl chains of the surfactant molecules. As the number of carbon atoms in the hydrophobic moiety increases, the interfacial tension values decrease.

\section{Critical Micelle Concentration (CMC)}

Concentration of CMC is reached when there is no change in interfacial tension value of the solution. The interfacial tension curves of APG-12 and APG-14 in Fig. 4 have two parts: (1) at lower concentrations there is a sudden decrease in the interfacial tension values, indicating that no micellization has occurred; (2) at higher concentrations, the curves decrease in a slow manner, and the break point concentration indicates that micellization has been occurred (micellization point). With further increase in the surfactant concentration there is no significant change in the interfacial tension values [5]. Concentration of CMC was identified at $3 \%, 1.32 \times 10^{-2}$ dyne/cm for surfactant APG-C12 and $3.72 \times$ $10^{-4}$ dyne/cm for surfactant APG-C14. Based on concentration of $\mathrm{CMC}$, which have low interfacial tension value. Surfactant APG-C12 and APGC-14 will be tested in phase bahaviour and capillary pressure test at $3-4 \%$ conc.

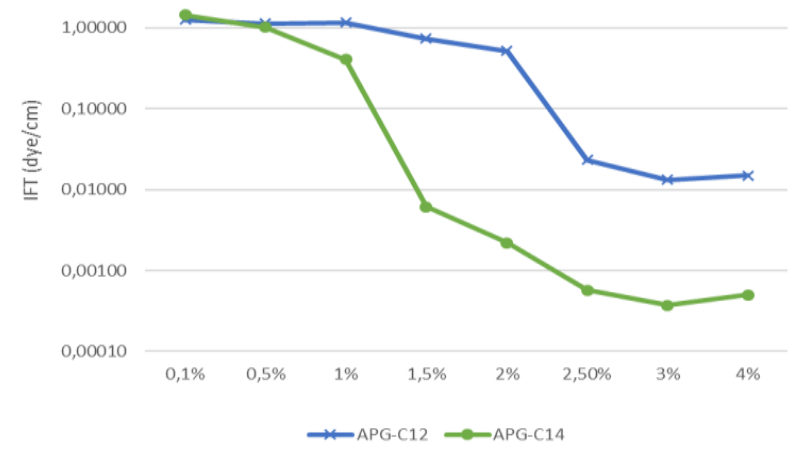

Fig. 4. Interfacial tension of APG-C12 and APGC-14 that show CMC.

\section{E. Phase Behavior Measurement}

The phase behavior was carried out to determine whether the emulsion formed was the upper phase emulsion, middle phase emulsion, or lower phase emulsion based on the Winsor system. The synthesized surfactant is expected to form a microemulsion, which is the middle phase emulsion was formed. It shown that both surfactant APG-C12 and APG-C14 has middle phase emulsion, although the emulsion on surfactant APG-C12 was thinner than the emulsion on surfactant APG-C14. Best middle phase emulsion that show at $3 \%$ concentration of surfactant APG-C14. Middle phase emulsion formed, show that interaction between hydrophobic side with oil and hydrofilic side with water was equal and causing low interfacial tension [9].

\section{F. Capillary Pressure Test}

Surfactant application tests were carried out to see the performance of surfactants against reservoir rocks, this can be done using the imbibition or core flooding method [10]. In this study, the application of synthesized alkyl polyglycoside surfactant as chemical flooding was carried out using the force imbibition method, better known as the capillary pressure test. Capillary pressure is the pressure difference between the fluid soaking the rock with a fluid that does not wet the rock if there are two or more fluid phases inside the rock that are not mixed.

Performance of Surfactant APG-12 dan APG-14 as chemical flooding were determined with capillary pressure method. The prepared core showed uniform characteristic as shown in Table IV, that make the core can be used for capillary pressure test. Capillary pressure test carried out in four steps, (1) saturating core using WP Jirak, (2) drainage method using Jirak oil, (3) imbibition method using WP jirak and (4) imbibition method using surfactant APG-12; APG-14.

TABLE IV: BEREA UPPER GRAY SANDSTONE CORE CHARACTERIZATION

\begin{tabular}{|c|c|c|c|c|c|}
\hline \multirow{2}{*}{ Properties } & \multicolumn{4}{|c|}{ Berea core number } & \multirow[t]{2}{*}{ Average } \\
\hline & 2 & 3 & 4 & 5 & \\
\hline Length $(\mathrm{cm})$ & 4.712 & 4.612 & 4.705 & 4.705 & $4.684 \pm 0.05$ \\
\hline $\begin{array}{l}\text { Diameter } \\
(\mathrm{cm})\end{array}$ & 3.785 & 3.784 & 3.786 & 3.786 & $3.785 \pm 0.001$ \\
\hline $\begin{array}{l}\text { Dry weight } \\
\text { (gr) }\end{array}$ & 113.031 & 110.409 & 112.641 & 111.227 & $111.827 \pm 1.22$ \\
\hline $\begin{array}{l}\text { Wet weight } \\
\text { (gr) }\end{array}$ & 123.030 & 120.350 & 122.750 & 121.120 & $121.813 \pm 1.29$ \\
\hline $\begin{array}{l}\text { Permeability } \\
\text { absolut gas } \\
(\mathrm{mD})\end{array}$ & 143.693 & 150.392 & 153.827 & 154.338 & $150.563 \pm 4.90$ \\
\hline Porosity (\%) & 19.389 & 19.819 & 19.689 & 19.445 & $19.586 \pm 0.20$ \\
\hline $\begin{array}{l}\text { Pore volume } \\
\text { (cc) }\end{array}$ & 10.280 & 10.280 & 10.429 & 10.300 & $10.322 \pm 0.07$ \\
\hline
\end{tabular}

Drainage method was conducted under a constant pressure to saturate the pores with oil and to accurately obtain the initial water saturation. After core saturated by oil, water flooding and surfactant flooding will increase water saturation $(\%)$ in core and oil production in system. The value of water saturation at the imbibition method shows the amount of formation water that drives crude oil out of the core. The pressure is gradually raised until no more water enters the core, this is indicated by the stable water saturation value. In this test, the maximum pressure used is 45 psi. The values of water saturation $(\%)$ at 45 psi for every steps in capillary pressure test are shown in Table V. From the CMC values and phase behavior test, the concentration of the aqueous solution APG-C12 and APG-C14 was determined at 3-4 wt $\%$, and will used as surfactant concentration at capillary pressure test.

\begin{tabular}{|c|c|c|c|}
\hline \multirow[b]{2}{*}{ Core no. } & \multicolumn{3}{|c|}{ Water saturation (\%) } \\
\hline & Drainage method & Water flooding & $\begin{array}{l}\text { Chemical } \\
\text { flooding }\end{array}$ \\
\hline Berea 2 & 24.214 & 77.498 & 86.576 \\
\hline Berea 3 & 23.688 & 75.727 & 85.005 \\
\hline Berea 4 & 23.688 & 75.727 & 89.524 \\
\hline Berea 5 & 22.629 & 81.809 & 90.373 \\
\hline
\end{tabular}

The residual value of oil saturation shows the percentage of crude oil that is still left in the core. Based on the results of the capillary pressure test it can be seen that the surfactant APG-C14 push more oil than the surfactant APG-C12. In addition, APG-C14 surfactants successfully recovered oil at lower concentrations compared to APG-C12 surfactants. This can be seen from the value of $\%$ recovery oil for APG-C14 surfactant with a concentration of $3 \%$ which is $13,797 \%$, while $\%$ recovery oil for APG-C12 surfactant with 
a concentration of $4 \%$ is $10.733 \%$, it show that alkyl chain length can improved the behavior of the surfactant system, thereby slightly improving the oil production (Table VI).

TABEL VI: RESIDUAL OIL SATURATION (SOR) AND VOLUME OIL OUT BY CHEMICAL FLOODING (IMBIBITION METHOD)

\begin{tabular}{cccccc}
\hline $\begin{array}{c}\text { Core } \\
\text { no. }\end{array}$ & $\begin{array}{c}\text { Conentration } \\
\text { of } \\
\text { surfactant, } \%\end{array}$ & $\begin{array}{c}\text { SOR by } \% \\
\text { WP } \%\end{array}$ & $\begin{array}{c}\text { SOR by } \\
\text { chemical } \\
\text { flooding, } \\
\%\end{array}$ & $\begin{array}{c}\text { Recovery } \\
\text { Oil by } \\
\text { chemical } \\
\text { flooding, } \\
\%\end{array}$ & $\begin{array}{c}\text { Volume } \\
\text { Oil Out by } \\
\text { chemical } \\
\text { flooding, } \\
\text { cc }\end{array}$ \\
\hline $\begin{array}{c}\text { Berea } \\
2\end{array}$ & $\begin{array}{c}\text { APG-C12, } \\
3 \%\end{array}$ & 22.502 & 13.424 & 9.078 & 0.9332 \\
$\begin{array}{c}\text { Berea } \\
3\end{array}$ & $\begin{array}{c}\text { APG-C12, } \\
4 \%\end{array}$ & 25.728 & 14.995 & 10.733 & 1.1033 \\
$\begin{array}{c}\text { Berea } \\
4\end{array}$ & $\begin{array}{c}\text { APG-C14, } \\
3 \%\end{array}$ & 24.273 & 10.476 & 13.797 & 1.4389 \\
Berea & APG-C14, & 18.191 & 9.627 & 8.564 & 0.8821 \\
5 & $4 \%$ & & & & \\
\hline
\end{tabular}

\section{CONCLUSION}

The surfactant APG various with alkyl chain length was synthesized using indirect method and characterization was analyzed by FTIR spectroscopy. The characteristic absorption of ether linkage (C-O-C) formed due to $\mathrm{OH}$ condensation is a weak band in the range $1715-1722.43 \mathrm{~cm}^{-1}$. The APG with alkyl chain length, there is APG-C14 has low IFT $3.72 \times 10^{-4} \mathrm{dyne} / \mathrm{cm}$ at critical micelle concetration (3\%) than APG-C12 $1.32 \times 10^{-2} \mathrm{dyne} / \mathrm{cm}$ at the same concentration. The phase behavior measurement was performed with variable surfactant concentrations WP and oil of Jirak. The results show that middle phase emulsion was formed at $3 \%$. Chemical flooding at capillary pressure test show that oil recovery APG-C14 13.797\% at 3\% and APG-C12 10.733\% at $4 \%$, it confirmed that alkyl chain length (APG-C14) has a good potential as surfactant properties for EOR.

\section{ACKNOWLEDGMENT}

The authors would like to say thank you to PT Pertamina (Persero) for the use of support financial and facilities.

\section{REFERENCES}

[1] Tirta, in Pertamina meeting of EOR project 2017.

[2] D. Eyl, "Enhanced oil recovery of heavy oil by using thermal and non thermal methods," Ph.D. dissertation, Dalhousie Univ., Nova Scotia, Canada, 2012.

[3] H. Y. Jang, K. Zhang, B. H. Chon, and H. J, Choi, "Enhanced oil recovery performance and viscosity characteristics of polysaccharide xanthan gum solution," Journal of Industrial and Eng. Chem., vol 21, pp. 228-233, Jan. 2015.

[4] E. Tobing, and S. W. Pratomo, Implementation of Enhance Water Flooding 1974, Indonesia: 2001, pp. 3-5.

[5] M. M. A. El-Sukkary, N. A. Syed, I. Aiad, and W. I. M. El-Azab, "Synthesis and characterization of some Alkyl Polygycosides surfactant," Journal of Surfactants and Detergents, vol. 11, pp. 129137, March 2008.

[6] M. Drew, Surfactant Science and Technology, 3rd ed. Hoboken, New Jersey, John Wiley \& Sons, Inc., 2006, pp. 69-73.

[7] J. L. Salager, "Surfactant types and uses, version 2, FIRP booklet \#E300-A: Teaching aid in surfactant science \& engineerin in English," Universidad De Los Andes, Merida-Venezuela, 2002.

[8] Z. Xu and J. S. Moore, "Synthesis and characterization of Alkyl polyglycoside," Chem. Int. Ed. Engl., vol. 2, pp. 246-248, Feb. 1993.

[9] E. J. Gudiña, V. Rangarajan, R. Sen, and L. R. Rodrigues, "Potential therapeutic applications of biosurfactants," Trends in Pharmacological Sciences, vol. 12, pp. 667-675, May 2013.

[10] E. Nopianto, "Metil ester sulfonat from palm stearinfor enhanced water flooding," S. T. thesis, Fac. of Agricultural Eng., Indonesia, 2011.

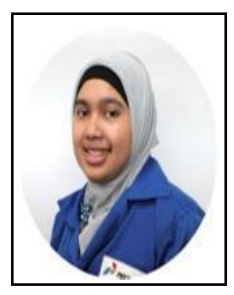

Agnesya Putri Gustianthy was born in Jakarta, $7^{\text {th }}$ August 1984. In 2006 she received bachelor degree in chemical engineering and then in 2019 she received master degree in chemistry at Universitas Indonesia, Indonesia. Her main interest was in material and chemical that can be applied in oil and gas industries, such as surfactant.

In 2006 she was a chemist at NIKE Indonesia Development Center and in 2009 she was join PT Pertamina (Persero) a nasional oil company of Indonesia. She started her career at PT Pertamina (Persero) as a chemical engineer for refinery area, then in 2012 she becomes a laboratory analyst of catalyst and material and in 2017 she was work as a specialist of material \& chemical research in research \& technology center Pertamina. Her current research area was a chemical for oil and gas industries such as corrosion inhibitor, demulsifier, antifoam, and surfactant especially for EOR application.

Mrs. Gustianthy is a member of IATMI and she also has a certificate as an radiation protection officer. In 2017 she was selected as a speaker for Corrosion Inhibitor Evaluation In Refinery at Conference Material Society of Indonesia. And in 2018 she was selected as a speaker for Corrosion International Conference held by NACE Western Area Conference in Seattle.

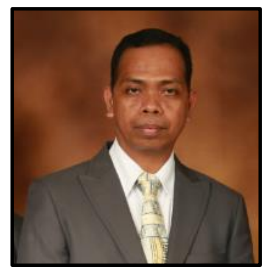

Usman M.Si was born in Buton, on $1^{\text {st }}$ January 1972. In 2007 he received doctoral degree in material science department at Simane University Japan. His main interest was in material, catalyst and chemical that can be applied in oil and gas industries.

In 1998 he was a lecture at Haluoleo University of Indonesia in chemistry department and in 2003 he work as a Research and development manager at EON Chemicals until 2010. He joined PT Pertamina (Persero) on 2010 as a hydroprocessing catalyst expert. In 2014 he moved as a researcher to Research \& Technology Center of Pertamina focused on chemical and petrochemical research. His current research area is material \& chemical for oil and gas industries such as corrosion inhibitor, demulsifier, antifoam, surfactant especially for EOR application, and bitumen.

Mr. Usman is a member of Asean Council on Petroleum (ASCOPE) since 2014 as Policy Research \& Capability Building Taskforc

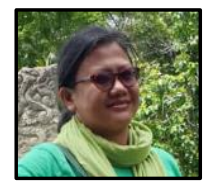

Yuni K. Krisnandi carried out project on study on ETS-10 titanosilicate as photocatalysts for her master and $\mathrm{PhD}$ studies under supervision of professor Russell Howe. In 2007-2009 she had an opportunity to carry out postdoc at Leibniz Institute for Catalysis (LIKAT) in Berlin, Germany. Her main research project was etherification of glycerol using Cs/zeolite. When returning to UI, she became a secretary for postgraduate programme at Department of Chemistry until 2010. Then, she was selected to be one of the $2^{\text {nd }}$ batch of UI research core lecturers (Dosen inti penelitian). As results, in 2013 she started her own group research: Solid Inorganic Framework, and actively received research grants, from UI, Indonesia, and abroad. She teaches some inorganic Chemistry subjects, aluminasilicate compounds, solid state chemistry and research methodology (master programme). In 2013 she was the PI of "Chemical Safety and Security Enhancement at the Department of Chemistry Universitas Indonesia" funded by The U.S. Department of State's Chemical Security Engagement Program (CSP). While in 2014 she received Research Grant for Basic Science Individual Scientist from UNESCO-TWAS (Synthesis and characterization of heterogeneous zeolite catalysts in biomass conversion to chemicals). She is member of editorial board of Makara J. Sci since 2015. Besides teaching and research, she also takes part in academic quality assurance activities. In 2012, she was the task-force leader for 'Self-Assessment Report' for AUN-QA assessment for undergraduate programme at Department of Chemistry. Since February 2015 she has been appointed as Deputy of Academic Affair at Academic Quality Assurance Board (BPMA-UI). Her award is the first 40 ALMI member since August 2016 until now. Her research link is Newton fund 2015, collaboration with Prof. Howe (University of Aberdeen, UK). 